\title{
PENGGUNAAN AKRONIM BAHASA MELAYU MANADO DI SMP NEGERI 8 MANADO PROVINSI SULAWESI UTARA
}

\author{
Pamela Clara Loindong \\ pamelaloindong@gmail.com \\ Gayda Bachmid \\ Djeinnie Imbang \\ Pascasarjana \\ Universitas Sam Ratulangi
}

\begin{abstract}
This research focused on the micro linguistic, where the object of study is on the morphology associated with the use of acronym of Bahasa Melayu Manado in SMP Negeri 8 Manado and was also associated with linguistic macro, focusing on sociolinguistics that will investigate the differences in age, sex and social interaction that led to the development, changes and differences in the use of acronyms, for both the teachers and students at SMP Negeri 8 Manado.

The results showed that of the 104 acronyms found in SMP Negeri 8 Manado, 103 of which are in accordance with the theory of Kridalaksana (2009), McCully, Holmes (1988) and Hartanto. The acronym classification consists of an acronym formed from two words, three words, four words and five words. Based on the formation process there are 30 process of formation of new acronyms outside Kridalaksana theory. While the sociolinguistic factors based on Peter Trudgil's theory leads to differences in the use of the acronym in Bahasa Melayu Manado among teachers and students at SMP Negeri 8 Manado are ages, situations and interactions.
\end{abstract}

Keywords: acronym, forms, sociolinguistic factors

\section{Pendahuluan}

Bahasa merupakan salah satu sarana komunikasi manusia melalui interaksi sosial dengan sesamanya. Bahasa dapat berfungsi jika saling memahami atau mengerti. Bahasa sangatlah penting dan dibutuhkan dalam kehidupan umat manusia. Apabila bahasa itu tidak ada, maka seseorang tidak dapat menyampaikan maksud dan tujuannya, sehingga akhirnya akan muncul kebisuan yang tidak menghasilkan apa-apa. Dalam Kamus Besar Bahasa Indonesia (KBBI Daring 2016) dinyatakan bahwa bahasa adalah sistem lambang bunyi yang arbitrer, yang digunakan oleh anggota suatu masyarakat untuk bekerja sama, berinteraksi, dan mengidentifikasikan diri-kalangan bahasa (katakata) yang lazim dipakai dalam lingkungan pekerjaan dan lain sebagainya. Sedangkan, menurut Chomsky (2002) bahasa adalah kumpulan kalimat, masing-masing dengan 
panjang tertentu dan dibangun oleh kumpulan elemen tertentu. Dengan demikian, dapat disimpulkan bahwa pengertian bahasa ialah sebuah sistem yang teratur dan berupa berbagai lambang bunyi yang dipakai dalam mengekspresikan pikiran serta perasaan dari pemakai bahasa tersebut.

Bahasa Indonesia adalah bahasa nasional yang digunakan di negara Republik Indonesia. Bahasa Indonesia lahir pada tanggal 28 Oktober 1928. Keputusan Kongres Bahasa Indonesia II tahun 1954 di Medan, antara lain, dinyatakan bahwa bahasa Indonesia berasal dari bahasa Melayu. Bahasa Indonesia tumbuh dan berkembang dari bahasa Melayu yang sejak zaman dulu sudah dipergunakan sebagai bahasa perhubungan (lingua franca) bukan hanya di Kepulauan Nusantara, melainkan juga hampir di seluruh Asia Tenggara (Marsono 2011).

Bahasa Melayu Manado merupakan salah satu bahasa daerah yang digunakan di kota Manado. Berbagai sumber menyebutkan bahwa awal mula Bahasa Melayu Manado banyak dipakai oleh para pedagang saat bertransaksi di Pelabuhan Laut Manado. Bahasa tersebut kemudian berkembang, berterima dan digunakan di kota Manado. Di Minahasa Bahasa Melayu Manado digunakan sebagai bahasa perantara antar kelompok etnis (Warokka 2004).

Kajian ilmiah terhadap bahasa disebut linguistik. Secara umum linguistik dapat dikatakan merupakan ilmu yang mempelajari bahasa sebagai objeknya. Linguistik adalah ilmu yang merupakan penyelidikan bahasa secara ilmiah. Definisi itu mungkin dapat diperjelas sedikit dengan menguraikan secara lebih terperinci pengertianpengertian yang terkandung dalam batasan ilmiah yang dapat dibedakan menjadi linguistik mikro (mikrolinguistik) dan linguistik makro (makrolinguistik). Linguistik mikro kajiannya pada struktur internal bahasa. Dalam linguistik mikro mencakup sejumlah sub-disiplin di antaranya: fonologi yang menyelidiki tentang bunyi bahasa, morfologi yang menyelidiki tentang morfem atau kata dan proses-proses pembentukannya, sintaksis yang menyelidiki tentang satuan-satuan kata yang terhimpun dalam kalimat, semantik yang menyelidiki makna bahasa dan leksikologi yang menyelidiki leksikon atau kosakata.

Linguistik makro terdapat beberapa sub-disiplin di antaranya: psikolinguistik yang mempelajari hubungan antara bahasa dengan perilaku dan akal budi manusia, juga 
sosiolinguistik yang mempelajari hubungan dan saling pengaruh antara perilaku bahasa dan perilaku sosial (Kridalaksana 2009).

Penelitian ini difokuskan pada linguistik mikro yang objek kajiannya pada morfologi yang terkait dengan penggunaan akronim Bahasa Melayu Manado di SMP Negeri 8 Manado Provinsi Sulawesi Utara. Penelitian ini juga dikaitkan dengan linguistik makro yang berfokus pada sosiolinguistik yang akan menyelidiki perbedaan usia, jenis kelamin dan interaksi sosial yang menyebabkan perkembangan, perubahan dan perbedaan penggunaan akronim, baik pada guru maupun siswa di SMP Negeri 8 Manado.

Membahas objek penelitian akronim kedudukannya bernaung dalam salah satu unsur internal linguistik yaitu morfologi.

\begin{abstract}
Morphology is a part of linguistic competence involves the ability to construct and interpret words. The system of categories and rules involved in word formation is called morphology. Morphological analysis focusses on the lexicon, or dictionary, component of the grammar. The lexicon consists of two parts. The first is a list of all the items in the vocabulary of the language. The lexical entry for each item includes information about its pronunciation, its meaning, its syntactic category and subcategorization frame, and various related facts. (O'Grady and Dobrovolsky 1987)
\end{abstract}

Morfologi adalah bagian dari kompetensi linguistik melibatkan kemampuan untuk menyusun dan menafsirkan kata-kata. Sistem kategori dan aturan yang terlibat dalam penyusunan kata disebut morfologi. Analisis morfologi berfokus pada leksikon, atau kamus, komponen tata bahasa. Leksikon terdiri dari dua bagian. Yang pertama adalah daftar semua item kosakata dalam bahasa. Entri leksikal untuk setiap item termasuk informasi tentang pengucapan, arti, kategori sintaksis dan bagan subkategorisasi, dan berbagai fakta terkait. (O'Grady and Dobrovolsky 1987)

Dengan kata lain morfologi adalah cabang linguistik yang mengidentifikasi satuan-satuan dasar bahasa sebagai satuan gramatikal. Morfologi mempelajari selukbeluk pembentukan kata serta pengaruh perubahan-perubahan bentuk kata terhadap golongan dan arti kata. Ada beberapa jenis pembentukan kata baru (word formation) secara bebas misalnya clipping, acronym, dan lain sebagainya (Plag 2002).

Akronim adalah kependekan yang berupa gabungan huruf atau suku kata atau bagian lain yang ditulis dan dilafalkan sebagai kata yang sesuai dengan kaidah fonotaktik bahasa bersangkutan. (Kridalaksana 2009)

Hal ini sejalan pula dengan McCully, Holmes (1988) sebagai berikut: 
The acronym must result in a phoneme sequence consisting of one or several syllables which correspond to the syllable structure of English. Example: CROP: Christian Rural Overseas Program, laser: Light Amplification by Stimulated Emission of Radiation. (McCully and Holmes 1988)

Akronim harus menghasilkan rentetan fonem yang mengandung satu atau sejumlah suku kata, yang berhubungan dengan struktur suku kata bahasa Inggris (atau dalam bahasa lainnya). Contoh: CROP: Christian Rural Overseas Program, laser: Light Amplification by Stimulated Emission of Radiation. (McCully and Holmes 1988)

Peneliti berupaya untuk menyelidiki Akronim Bahasa Melayu Manado yang digunakan di SMP Negeri 8 Manado Provinsi Sulawesi Utara dengan sejumlah alasan, pertama pengalaman empiris yang dialami peneliti yaitu saat mengunjungi sekolah tersebut. Peneliti menemukan sejumlah kata yang tidak lazim terdengar. Peneliti menanyakan mengenai istilah tersebut kepada sumbernya, di mana hasil yang pada mulanya diduga merupakan istilah tertentu, ternyata merupakan akronim dalam Bahasa Melayu Manado, seperti abunti (abu nawas tingkat tinggi) dan ISTI (ikatan suami tako istri). Dengan demikian, peneliti ingin mengetahui lebih dalam mengenai bentuk-bentuk akronim apa saja yang digunakan oleh guru-guru dan siswa-siswa di SMP Negeri 8 Manado. Tampaknya dengan menggunakan akronim, mereka tidak harus mengucapkan sederet kata-kata yang begitu panjang, tetapi cukup dengan menggunakan akronim sudah dapat terwakili maksud ungkapan dan tercipta komunikasi yang efektif. Kedua, peneliti menemukan dari hasil studi pendahuluan yaitu Astuti (2015) dalam penelitiannya yang berjudul "Singkatan dan Akronim di Kalangan Remaja di Kota Bandung" yang menggunakan teori Kridalaksana dan menemukan sepuluh jenis pola pembentukan singkatan baru dan 43 jenis pola pembentukan akronim baru.

Kedua alasan inilah yang menjadi dasar peneliti untuk melaksanakan penelitian mengenai bentuk-bentuk akronim dalam Bahasa Melayu Manado yang digunakan di SMP Negeri 8 Manado Provinsi Sulawesi Utara.

\section{Perumusan Masalah}

Berdasarkan latar belakang di atas, maka peneliti merumuskan masalah sebagai berikut: 
1. Bentuk akronim apa saja dalam Bahasa Melayu Manado yang digunakan di SMP Negeri 8 Manado Provinsi Sulawesi Utara?

2. Faktor-faktor apa saja yang menyebabkan perbedaan antara penggunaan akronim dalam Bahasa Melayu Manado di kalangan guru dan siswa di SMP Negeri 8 Manado Provinsi Sulawesi Utara?

\section{Tujuan Penelitian}

Berdasarkan rumusan masalah, yang menjadi tujuan penelitian yaitu:

1. Mengidentifikasi, mengklasifikasi, dan menjelaskan bentuk-bentuk akronim dalam Bahasa Melayu Manado yang digunakan di SMP Negeri 8 Manado Provinsi Sulawesi Utara berdasarkan proses pembentukannya.

2. Mendeskripsikan faktor-faktor penyebab perbedaan penggunaan akronim dalam Bahasa Melayu Manado antara guru dan siswa yang digunakan di SMP Negeri 8 Manado Provinsi Sulawesi Utara.

\section{Manfaat Penelitian}

1. Manfaat Teoretis

A. Penelitian ini bermanfaat bagi pengembangan bidang ilmu Linguistik khususnya mengenai bentuk-bentuk akronim dan hasil penerapan teori Kridalaksana (2009).

B. Memperkuat teori Sosiolinguistik dari Peter Trudgil yang menerangkan mengenai faktor-faktor yang menyebabkan terjadi variasi penggunaan bahasa, dalam hal ini variasi penggunaan akronim antara guru dan siswa di SMP Negeri 8 Manado.

2. Manfaat Praktis

A. Penelitian ini bermanfaat bagi masyarakat mengenai pengetahuan mereka akan akronim dalam Bahasa Melayu Manado dan variasi penggunaannya di SMP Negeri 8 Manado. Melalui penelitian ini pembaca diharapkan dapat terangsang kreativitasnya dalam menciptakan bentuk-bentuk akronim baru baik dalam bahasa Indonesia maupun bahasa daerah yang mungkin akan muncul di masa depan yang dapat membantu keefektifan dalam berkomunikasi kita semua. 
B. Penelitian ini juga dapat menjadi referensi bagi peneliti-peneliti selanjutnya yang ingin mengembangkan kajian ini lebih luas dan lebih komprehensif lagi. Semoga peneliti-peneliti selanjutnya dapat menemukan bentuk-bentuk dan proses pembentukan akronim yang baru dengan menggunakan bahasa Melayu-Manado, maupun bahasa daerah lainnya sebagai objek penelitian.

\section{Tinjauan Pustaka}

Astuti (2015) dalam penelitiannya yang berjudul "Singkatan dan Akronim di Kalangan Remaja di Kota Bandung" menggunakan teori Kridalaksana dan menemukan sepuluh jenis pola pembentukan singkatan baru dan 43 jenis pola pembentukan akronim baru.

Zaim (2015) dalam kajiannya yang berjudul "Pergeseran Sistem Pembentukan Kata Bahasa Indonesia: Kajian Akronim, Blending, dan Kliping”, memakai teori pembentukan kata dari Booij, Meliono, Alwi dkk, mendeskripsikan temuan yang didapati tentang adanya aturan pembentukan kata dan pergeseran pembentukan kata, khususnya pada akronim, blending, dan kliping dalam bahasa tulis Bahasa Indonesia.

Marthawati (2011) melakukan penelitian mengenai "Penggunaan Istilah, Deiksis, Singkatan, dan Akronim dalam Situs Jejaring Sosial Facebook". Ia menggunakan teori Kridalaksana, dan hasilnya ditemukan beberapa istilah, singkatan dan akronim yang mengalami perubahan makna dan ada pula istilah, singkatan, dan akronim baru yang dibentuk karena adanya konsep baru yang sengaja digunakan sebagai bahan kelucuan atau keanehan antar pengguna situs jejaring sosial Facebook.

Kurniasari dan Budiman (2014) dalam meneliti "Pemilihan Bahasa pada Multibahasawan: Kajian Sosiolinguistik Pemilihan Bahasa pada Mahasiswa Kebumen di UI" mengatakan bahwa masyarakat multibahasa melakukan pemilihan bahasa dalam interaksi sosial sesuai dengan berbagai faktor seperti latar dan situasi interaksi, partisipan dalam interaksi, topik pembicaraan, dan fungsi interaksi. Mahasiswa UI yang mereka teliti yang berasal dari Kebumen merupakan contoh masyarakat multilingual sehingga mahasiswa ini juga harus melakukan pemilihan bahasa dalam berinteraksi. Pemilihan bahasa sangat penting dilakukan mengingat bahasa merupakan cerminan dari kesantunan dan keakraban seseorang dalam bersosialisasi. 
Deliani (2014) dalam penelitiannya yang berjudul "Exploring Acronym in Indonesian Language; Structure Formation and Internal Syllable" menganalisis proses pembentukan akronim dalam Bahasa Indonesia berdasarkan teori morfologis dan struktur suku kata internal. Hasilnya menunjukkan proses pembentukan akronim dapat diklasifikasikan menjadi enam cara. Juga terdapat serta struktur suku kata internal yang menunjukkan tujuh tipe struktur susunan huruf vokal dan konsonan.

Prastya (2014) dalam penelitiannya yang berjudul "Analisis Bahasa Graffiti Tembok di Kota Surakarta: Tinjauan Sosiolinguistik" menyimpulkan bahwa di Kota Surakarta terdapat 5 bentuk ungkapan pada graffiti yaitu, kata, frase, klausa, kalimat, dan wacana. Ungkapan pada graffiti tembok di Kota Surakarta berupa kritik sosial dengan fungsi yang variatif.

Harimansyah (2011) dengan kajiannya yang diberi judul "Diksi Laki-laki dan Perempuan dalam Puisi-Mutakhir Indonesia (Kajian Sosiolinguistik-Genderistik)" memaparkan perbedaan pilihan bahasa antara laki-laki dan perempuan dalam pemakaian bahasa karya sastra, khususnya dalam puisi-puisi Indonesia mutakhir yang muncul antara tahun 1990-2000. Harimansyah menemukan bahwa ideologi linguistik laki-laki dan perempuan dalam bahasa puisi difungsikan untuk membentuk dan mengungkapkan ekspresi dan gagasan penyair sekaligus disertai nuansa sikap penuturnya sendiri yang tidak terlepas dari isu genderistik yang beredar di dalam masyarakat.

Al Fithriyah (2013) yang meneliti "Variasi Bahasa pada Dialog Film Red Cobex: Kajian Sosiolinguistik" menyimpulkan banyak ditemukan dialek yang dipakai dalam film ini, yang diketahui dengan adanya sejumlah leksikon struktur fonemis dan intonasi dialek yang khas, sehingga dapat membedakan antara dialek yang satu dengan dialek yang lainnya. Juga ditemukan adanya variasi sosiolek dari segi pendidikan, jenis kelamin, dan pekerjaan.

Ana (2010) dengan penelitiannya yang berjudul "Akronim dalam Bahasa Indonesia: Tinjauan Linguistik dan Sosio-Politis Perkembangannya" mengemukakan bahwa di samping berfungsi sebagai pemendekan frase atau nama, akronim juga berfungsi sebagai semboyan dan media humor. Secara politis, pelembagaan akronim didasarkan pada alasan: (a) mengkomunikasikan identitas (daerah), (b) dorongan spiritual nasionalis dan religius, dan (c) pemitosan pada masa lalu. Selain itu, duga 
dikemukakan bahwa perkembangan dan penggunaan akronim dalam bahasa Indonesia perlu terus didorong sesuai dengan perkembangan masyarakat dan budayanya, namun perlu terus dikontrol agar penggunaannya tetap mengacu pada kaidah tata nilai budaya, serta sosio-politis yang ada.

Giyatmi, dkk (2014) melakukan penelitian yang berjudul "The Analysis of English Word Formations Used on Brand Names Found in Indonesian Products". Hasil penelitian mereka menjelaskan bagaimana nama dagang dengan bahasa Inggris di produk Indonesia diciptakan dengan menggunakan jenis-jenis pembentukan kata, beberapa di antaranya berupa singkatan dan akronim.

Susdamita, dkk (2015) meneliti “Akronim dalam Indonesia Lawak Klub (ILK)". Mereka melakukan analisis penggunaan akronim dalam sebuah acara lawak dan menemukan klasifikasi akronim berbentuk nama diri yang berupa singkatan dari beberapa unsur ditulis dengan huruf awal kapital sebagai bentuk yang dominan, dengan didasari oleh pembentukan fungsi pragmatis.

Dhianari (2011) melakukan penelitian mengenai singkatan dan akronim yang digunakan di komunitas jejaring sosial Kaskus dengan judul "Ragam Bahasa Kaskus". Pada penekanan bagaimana terbentuknya akronim-akronim tersebut yang sesuai dengan teori semiotik dari Charles Sanders Pierce. Hasil penelitiannya adalah bentuk-bentuk ragam bahasa yakni singkatan, akronim, RBK bentuk ringkas, RBK bentuk pelesetan, RBK yang mengalami penyederhanaan pelafalan, dan RBK bentuk campuran..

Berdasarkan uraian tinjauan pustaka di atas tidak ditemukan penelitian akronim dalam Bahasa Melayu Manado. Peneliti memilih untuk meneliti mengenai akronim dalam Bahasa Melayu Manado dengan harapan setelah proses penelitian ini berakhir, peneliti dapat menemukan bentuk-bentuk akronim serta proses pembentukan baru dari akronim Bahasa Melayu Manado. Peneliti dapat mengembangkan dan mengisi kekosongan yang ada dari penelitian-penelitian yang telah dilakukan sebelumnya. Selain itu peneliti dengan menggunakan teori Sosiolinguistik juga dapat menjelaskan faktor-faktor yang menyebabkan perbedaan antara penggunaan akronim dalam Bahasa Melayu Manado di kalangan guru dan siswa di SMP Negeri 8 Manado Provinsi Sulawesi Utara. 


\section{Kerangka Teoretis}

Menurut Kerlinger (1973), teori merupakan seperangkat konsep, definisi dan proposisi yang berfungsi untuk melihat fenomena secara sistematik, melalui spesifikasi hubungan antara variabel sehingga dapat berguna untuk menjelaskan dan meramalkan fenomena. Kerangka teoretis yang digunakan oleh peneliti dalam penelitian ini adalah gabungan pendapat para ahli mengenai akronim dan Sosiolinguistik.

Akronim adalah kependekan yang berupa gabungan huruf atau suku kata atau bagian lain yang ditulis dan dilafalkan sebagai kata yang sesuai dengan kaidah fonotaktik bahasa bersangkutan. (Kridalaksana 2009)

The acronym must result in a phoneme sequence consisting of one or several syllables which correspond to the syllable structure of English. Example: CROP: Christian Rural Overseas Program, laser: Light Amplification by Stimulated Emission of Radiation. (McCully and Holmes 1988)

Akronim harus menghasilkan rentetan fonem yang mengandung satu atau sejumlah suku kata, yang berhubungan dengan struktur suku kata bahasa Inggris (atau bahasa lainnya). Contoh: CROP: Christian Rural Overseas Program, laser: Light Amplification by Stimulated Emission of Radiation. (McCully and Holmes 1988)

As defined by Webster's dictionary, acronym is a word formed from the initial letters of the successive parts of a compound term. (ex: radar). (Merriam-Webster 2016)

Seperti yang ditulis dalam Kamus Webster's Dictionary, akronim adalah kata yang terbentuk dari huruf awal dari istilah komponen yang bersusulan (contoh: radar). (Merriam-Webster 2016)

Hartanto (1995) menjelaskan akronim adalah bentuk singkatan yang berupa gabungan huruf awal, gabungan suku kata ataupun kombinasi huruf dan suku kata dari deret kata dan yang ditulis serta dilafalkan sebagai kata yang wajar; contoh Mayjen (Mayor Jenderal).

Sosiolinguistik yaitu cabang linguistik yang berusaha untuk menjelaskan ciri-ciri variasi bahasa dan menetapkan korelasi ciri-ciri variasi bahasa tersebut dengan ciri-ciri sosial. (Kridalaksana dalam Pateda, 1987)

Booij, Kerstens dan Verkuyl dalam Pateda (1987) mengatakan "Sociolinguistiek is subdiscipline van de taalkunde, die bestudeert welke socialefactoren een rol spelen in het taalgebruik er welke rol taal speelt in het sociaal verkeer" (sosiolinguistik adalah 
cabang linguistik yang mempelajari faktor-faktor sosial yang berperan dalam pemakaian bahasa dan yang berperan dalam pergaulan).

Nancy Parrot Hickerson dalam Pateda (1987) mengatakan "Sociolinguistic is a developing subfield of linguistics which takes speech variation as its focus, viewing variation or its social context. Sociolinguistics is concerned with the correlation between such social factors and linguistic variations".

Menurut Peter Trudgil (1986), penggunaan bahasa dapat dipengaruhi oleh kelas sosial, kelompok etnis, jenis kelamin, situasi, interaksi sosial, kewarganegaraan, dan lingkungan tempat tinggal.

\section{Metodologi Penelitian}

Berdasarkan masalah yang disajikan, penelitian ini menggunakan metode kualitatif yang bersifat deskriptif yakni metode analisis verbal non angka untuk menjelaskan makna lebih jauh dari yang tampak oleh pancaindra. Menurut (Kasiram 2010), penelitian kualitatif adalah suatu konsep keseluruhan untuk mengungkapkan rahasia tertentu, dilakukan dengan menghimpun data dalam keadaan sewajarnya, mempergunakan cara bekerja yang sistematik, terarah, dan dapat dipertanggungjawabkan, sehingga tidak kehilangan sifat ilmiahnya atau serangkaian kegiatan atau proses menjaring data/informasi yang bersifat sewajarnya mengenai suatu masalah dalam kondisi aspek atau bidang tertentu pada objeknya. Dengan kata lain, metode ini menggambarkan segala sesuatu secara apa adanya dengan data yang dikumpulkan sesuai dengan kenyataan yang terdapat pada objek penelitian.

\section{Tempat dan Waktu Penelitian}

Tempat penelitian dilaksanakan di SMP Negeri 8 Manado dan waktu penelitian berjalan selama tiga bulan. SMP Negeri 8 Manado adalah lembaga pendidikan formal dalam pendidikan dasar yang didirikan pada tahun 1979 dan diresmikan pada tanggal 22 September 1981 yang dibangun di atas lahan $\pm 10.000 \mathrm{~m}^{2}$, luas tanah terbangun $\pm 2.436 \mathrm{~m}^{2}$. Alamat sekolah ini berada di Jalan Sea Malalayang Satu Barat. 


\section{Informan}

Informan berjumlah 96 orang, 10 orang guru dan 86 orang siswa. Samarin (1988) menyatakan bahwa informan adalah orang yang memperlengkapi peneliti dengan contoh-contoh bahasa, baik sebagai ulangan dari apa yang sudah diucapkan maupun sebagai bentukan tentang apa yang mungkin dikatakan orang.

\section{Metode Pengumpulan Data}

Metode pengumpulan data yang peneliti lakukan adalah metode simak dan cakap dengan wawancara terstruktur disertai dengan kuesioner dan wawancara tidak terstruktur. Menurut Mahsun (2005) metode simak adalah metode pengumpulan data yang dilakukan dengan menyimak penggunaan bahasa pada guru dan siswa yang ada di SMP Negeri 8 Manado Provinsi Sulawesi Utara. Istilah menyimak di sini berkaitan dengan penggunaan bahasa secara lisan. Teknik catat adalah teknik lanjutan yang dilakukan ketika menerapkan metode simak.

\section{Teknik Analisis Data}

Analisis data dilakukan setelah pengumpulan data melalui wawancara yang dilakukan peneliti secara langsung dan kuesioner yang dibagikan. Sugiyono (2009) menyatakan bahwa analisis bahasa meliputi kegiatan reduksi data, penyajian data dan kesimpulan. Data mengenai akronim yang berhasil dikumpulkan kemudian diklasifikasi berdasarkan teori Kridalaksana (2009), McCully, Holmes (1988) dan Hartanto. Untuk menganalisis bagaimana proses pembentukan akronim-akronim tersebut, teori yang akan digunakan adalah teori dari Kridalaksana (2009) dan untuk mengetahui mengapa terjadi perbedaan penggunaan akronim antara guru dan siswa akan digunakan teori mengenai sosiolinguistik dari Peter Trudgil.

\section{Pembahasan}

Bentuk-bentuk Akronim dalam Bahasa Melayu Manado yang Digunakan di SMP Negeri 8 Manado Provinsi Sulawesi Utara

\begin{tabular}{|l|l|l|l|}
\hline № & \multicolumn{1}{|c|}{ Akronim } & \multicolumn{1}{c|}{ Kepanjangan } & \multicolumn{1}{c|}{ Arti dalam Bahasa Indonesia } \\
\hline 1. & abunti & $\begin{array}{l}\text { abunawas tingkat } \\
\text { tinggi }\end{array}$ & pembohong besar \\
\hline
\end{tabular}




\begin{tabular}{|c|c|c|c|}
\hline № & Akronim & Kepanjangan & Arti dalam Bahasa Indonesia \\
\hline 2. & alim, almi & anak licik munafik & $\begin{array}{l}\text { anak yang bersifat licik dan } \\
\text { munafik }\end{array}$ \\
\hline 3. & anoa & anak ontak anjing & anak yang nakal dan bebal \\
\hline 4. & asben & asal bengko & $\begin{array}{l}\text { mengatakan sesuatu secara asal- } \\
\text { asalan }\end{array}$ \\
\hline 5. & asbun, asbu & asal bunyi & $\begin{array}{l}\text { berbicara tanpa berpikir terlebih } \\
\text { dahulu }\end{array}$ \\
\hline 6. & asigoma & $\begin{array}{l}\text { anak hasil goyangan } \\
\text { mama }\end{array}$ & wanita yang lihai di tempat tidur \\
\hline 7. & asigopa & $\begin{array}{l}\text { anak hasil goyangan } \\
\text { papa }\end{array}$ & $\begin{array}{l}\text { anak yang memiliki sifat-sifat } \\
\text { buruk ayahnya }\end{array}$ \\
\hline 8. & aspek & asal spekol & $\begin{array}{l}\text { menjawab suatu pertanyaan tanpa } \\
\text { berpikir terlebih dahulu }\end{array}$ \\
\hline 9. & astuj & asal tunjung & menuduh tanpa bukti \\
\hline 10. & bakso & batak soe & $\begin{array}{l}\text { orang dari etnis Batak yang } \\
\text { membawa sial }\end{array}$ \\
\hline 11. & barito & bawang rica tomat & $\begin{array}{l}\text { kumpulan bahan makanan: bawang, } \\
\text { merica dan tomat }\end{array}$ \\
\hline 12. & beti & beda tipis & berbeda sedikit sekali \\
\hline 13. & bika & bibir karlota & orang yang suka bergosip \\
\hline 14. & BIPRA & $\begin{array}{l}\text { bapak ibu pemuda } \\
\text { remaja anak }\end{array}$ & $\begin{array}{l}\text { susunan organisasi dalam Gereja } \\
\text { Masehi Injili di Minahasa, terdiri } \\
\text { dari: persekutuan ibadah bagi pria } \\
\text { yang sudah menikah (bapak), } \\
\text { wanita yang sudah menikah (ibu), } \\
\text { dewasa muda (pemuda), usia } \\
\text { remaja (remaja), anak-anak (anak) }\end{array}$ \\
\hline 15. & brakoca & brani kore pica & $\begin{array}{l}\text { jangan mengganggu, karena } \\
\text { konsekuensinya dapat berujung } \\
\text { pada kekerasan }\end{array}$ \\
\hline 16. & brakocah & brani kore picah & $\begin{array}{l}\text { jangan mengganggu, karena } \\
\text { konsekuensinya dapat berujung } \\
\text { pada kekerasan }\end{array}$ \\
\hline 17. & brakomada & $\begin{array}{l}\text { brani kore mandi } \\
\text { darah }\end{array}$ & $\begin{array}{l}\text { jangan mengganggu, karena } \\
\text { konsekuensinya dapat berujung } \\
\text { pada kekerasan }\end{array}$ \\
\hline 18. & brakomanda & $\begin{array}{l}\text { brani kore mandi } \\
\text { darah }\end{array}$ & $\begin{array}{l}\text { jangan mengganggu, karena } \\
\text { konsekuensinya dapat berujung } \\
\text { pada kekerasan }\end{array}$ \\
\hline 19. & buceri & bule cet sendiri & $\begin{array}{l}\text { orang yang mengecat pirang } \\
\text { rambutnya sendiri }\end{array}$ \\
\hline
\end{tabular}




\begin{tabular}{|c|c|c|c|}
\hline № & Akronim & Kepanjangan & Arti dalam Bahasa Indonesia \\
\hline 20. & cicago & $\begin{array}{l}\text { cina campur } \\
\text { gorontalo }\end{array}$ & $\begin{array}{l}\text { keturunan Cina campuran } \\
\text { Gorontalo }\end{array}$ \\
\hline 21. & cidija & cilaka di jalan & kecelakaan lalu-lintas \\
\hline 22. & cilo & cina loleng & keturunan Cina asli \\
\hline 23. & cupang & cucur panada apang & jenis-jenis kue khas Manado \\
\hline 24. & daboribo & $\begin{array}{l}\text { damai boleh ribut } \\
\text { boleh }\end{array}$ & $\begin{array}{l}\text { menanggapi kejadian sesuai } \\
\text { keadaan }\end{array}$ \\
\hline 25. & daribo & $\begin{array}{l}\text { damai boleh ribut } \\
\text { boleh }\end{array}$ & $\begin{array}{l}\text { menanggapi kejadian sesuai } \\
\text { keadaan }\end{array}$ \\
\hline 26. & dober & doi berkat & uang pemberian \\
\hline 27. & donat & doi natal & $\begin{array}{l}\text { angpau, khususnya pada saat hari } \\
\text { raya natal }\end{array}$ \\
\hline 28. & dotab & doi tahun baru & $\begin{array}{l}\text { angpau, khususnya pada saat hari } \\
\text { raya tahun baru }\end{array}$ \\
\hline 29. & gabet & gatal bete & genit \\
\hline 30. & gabostaso & $\begin{array}{l}\text { gabungan ontak setan } \\
\text { tapi sopan }\end{array}$ & $\begin{array}{l}\text { orang yang pemarah tapi bersikap } \\
\text { sopan }\end{array}$ \\
\hline 31. & golope & golojo pepe & memiliki nafsu berahi yang tinggi \\
\hline 32. & gope, gopek & gode pendek & gemuk dan pendek \\
\hline 33. & gope & golojo pepe & memiliki berahi yang tinggi \\
\hline 34. & goti & gode tinggi & gemuk dan tinggi \\
\hline 35. & hasigoma & hasil goyangan mama & $\begin{array}{l}\text { anak yang memiliki sifat-sifat } \\
\text { buruk ibunya }\end{array}$ \\
\hline 36. & hasigopa & hasil goyangan papa & $\begin{array}{l}\text { anak yang memiliki sifat-sifat } \\
\text { buruk ayahnya }\end{array}$ \\
\hline 37. & hugel & hubungan gelap & $\begin{array}{l}\text { hubungan perselingkuhan secara } \\
\text { diam-diam }\end{array}$ \\
\hline 38. & huter & hubungan terang & $\begin{array}{l}\text { hubungan perselingkuhan secara } \\
\text { terang-terangan }\end{array}$ \\
\hline 39. & imut & itang mutlak & memiliki warna kulit sangat gelap \\
\hline 40. & ISTI & $\begin{array}{l}\text { Ikatan Suami Tako } \\
\text { Istri }\end{array}$ & $\begin{array}{l}\text { sebutan untuk para suami yang } \\
\text { takut pada istrinya }\end{array}$ \\
\hline 41. & kabot & kaki botol & $\begin{array}{l}\text { memiliki bentuk kaki yang pendek } \\
\text { dan berisi }\end{array}$ \\
\hline 42. & kacepa & kacili ceper pasung & $\begin{array}{l}\text { berperawakan kecil dan memiliki } \\
\text { wajah yang cantik }\end{array}$ \\
\hline 43. & karbo & karong bocor & tukang gosip \\
\hline 44. & kuker & kurus kerempeng & kurus sekali \\
\hline 45. & kuper & kurang pergaulan & jarang bergaul \\
\hline 46. & lamu & lala mulu & cerewet \\
\hline
\end{tabular}




\begin{tabular}{|c|c|c|c|}
\hline № & Akronim & Kepanjangan & Arti dalam Bahasa Indonesia \\
\hline 47. & los & lorong orang sanger & $\begin{array}{l}\text { sebutan untuk lingkungan yang } \\
\text { mayoritas penduduknya berasal dari } \\
\text { etnis Sangihe }\end{array}$ \\
\hline 48. & mabager & malas bagera & malas beraktivitas \\
\hline 49. & malper & malalayang permai & $\begin{array}{l}\text { nama salah satu perumahan di } \\
\text { Manado }\end{array}$ \\
\hline 50. & mamam & main malam & keluar di malam hari \\
\hline 51. & mantos & manado town square & $\begin{array}{l}\text { sebuah pusat perbelanjaan di Kota } \\
\text { Manado }\end{array}$ \\
\hline 52. & midal & mie bedaal & $\begin{array}{l}\text { bubur Manado yang dicampur } \\
\text { dengan mi }\end{array}$ \\
\hline 53. & mintol & minta tolong & minta tolong \\
\hline 54. & mulos & mulu longsor & tidak bisa menyimpan rahasia \\
\hline 55. & mutu & muka tua & $\begin{array}{l}\text { orang yang terlihat lebih tua dari } \\
\text { usia yang sebenarnya }\end{array}$ \\
\hline 56. & nasgor & nasi goreng & nasi goreng \\
\hline 57. & naskun & nasi kuning & nasi kuning \\
\hline 58. & nensi & nenek sihir & $\begin{array}{l}\text { perempuan yang sifatnya jahat } \\
\text { seperti nenek sihir }\end{array}$ \\
\hline 59. & orbut & orang buta & orang buta \\
\hline 60. & paman & papa mantu & papa mertua \\
\hline 61. & panada & pak ani nda ada dana & $\begin{array}{l}\text { ayah baptis yang tidak bias } \\
\text { memberikan angpau pada hari raya }\end{array}$ \\
\hline 62. & pelacur & penada lalampa cucur & jenis-jenis kue khas Manado \\
\hline 63. & perancis & peranakan cina sanger & keturunan Cina campuran Sangihe \\
\hline 64. & pisgor & pisang goreng & pisang goreng \\
\hline 65. & polos & poco-poco lonte sadis & $\begin{array}{l}\text { wanita tuna susila yang } \\
\text { perawakannya berisi }\end{array}$ \\
\hline 66. & pramuka & $\begin{array}{l}\text { parampuang mulu } \\
\text { karlota }\end{array}$ & perempuan yang cerewet \\
\hline 67. & pupumatoli & $\begin{array}{l}\text { pucuk-pucuk mar } \\
\text { torang linca }\end{array}$ & orang-orang muda yang cekatan \\
\hline 68. & puti & puru timbul & gendut \\
\hline 69. & romantis & roko makang gratis & $\begin{array}{l}\text { pria yang bergantung pada } \\
\text { kekasihnya }\end{array}$ \\
\hline 70. & rumapega & rusak mama pe gaco & $\begin{array}{l}\text { anak yang terlanjur terlibat } \\
\text { pergaulan bebas }\end{array}$ \\
\hline 71. & sabata & sambarang tada & rakus (makanan), bergaul bebas \\
\hline 72. & salper & salah pergaulan & salah pergaulan \\
\hline
\end{tabular}




\begin{tabular}{|c|c|c|c|}
\hline № & Akronim & Kepanjangan & Arti dalam Bahasa Indonesia \\
\hline 73. & sarbeng, sarben & saraf bengko & $\begin{array}{l}\text { orang yang mudah marah/orang } \\
\text { yang mengalami gangguan jiwa }\end{array}$ \\
\hline 74. & sartum & sario tumpaan & $\begin{array}{l}\text { nama sebuah Kelurahan di Kota } \\
\text { Manado }\end{array}$ \\
\hline 75 . & sate & saat teduh & $\begin{array}{l}\text { saat beribadah khusyuk secara } \\
\text { pribadi }\end{array}$ \\
\hline 76. & sate & salah teduh & $\begin{array}{l}\text { saat beribadah khusyuk secara } \\
\text { pribadi }\end{array}$ \\
\hline 77. & seba & seks babi & $\begin{array}{l}\text { genit/penggila seks/orang yang } \\
\text { kecanduan hubungan seksual }\end{array}$ \\
\hline 78. & seba & seksi babi & $\begin{array}{l}\text { genit/penggila seks/orang yang } \\
\text { kecanduan hubungan seksual }\end{array}$ \\
\hline 79. & seti & seks tinggi & $\begin{array}{l}\text { orang yang menyukai hal-hal } \\
\text { elegan }\end{array}$ \\
\hline 80. & seti & seksi tinggi & $\begin{array}{l}\text { orang yang menyukai hal-hal } \\
\text { elegan }\end{array}$ \\
\hline 81. & seti & selera tinggi & $\begin{array}{l}\text { orang yang menyukai hal-hal } \\
\text { elegan }\end{array}$ \\
\hline 82. & setia & selingkuh tiada akhir & orang yang sering selingkuh \\
\hline 83. & sianida & siap nae isap dada & $\begin{array}{l}\text { genit/penggila seks/orang yang } \\
\text { kecanduan hubungan seksual }\end{array}$ \\
\hline 84. & singapur & singgah di dapur & mampir ke dapur \\
\hline 85 & smanix & sma negeri ix manado & $\begin{array}{l}\text { nama sebuah sekolah menengah } \\
\text { atas di Kota Manado }\end{array}$ \\
\hline 86. & smoking & smokol nasi kuning & sarapan dengan menu nasi kuning \\
\hline 87. & $\operatorname{tamu}$ & tau mulu & $\begin{array}{l}\text { orang yang tahu mana yang pantas } \\
\text { untuk diceritakan dan mana yang } \\
\text { tidak }\end{array}$ \\
\hline 88. & tikus & tinggi kurus & tinggi kurus \\
\hline 89. & toba & toto basar & payudara berukuran besar \\
\hline 90. & topa & toto pai & payudara berukuran besar \\
\hline 91. & tos & torang orang sea & $\begin{array}{l}\text { orang-orang yang tinggal di salah } \\
\text { satu daerah di Kota Manado }\end{array}$ \\
\hline 92. & unsrat & $\begin{array}{l}\text { universitas sam } \\
\text { ratulangi }\end{array}$ & $\begin{array}{l}\text { salah satu perguruan tinggi negeri } \\
\text { di Manado, Sulawesi Utara }\end{array}$ \\
\hline
\end{tabular}

Peneliti menemukan 104 akronim, 103 di antaranya sesuai dengan teori dari Kridalaksana (2009), McCully, Holmes (1988) dan Hartanto, sedangkan 1 akronim yaitu SMANIX tidak sesuai dengan teori-teori tersebut. Akronim SMANIX tidak sesuai 
dikarenakan IX pada akronim SMANIX adalah angka romawi dari huruf 9 (sembilan) yang dibaca menjadi huruf I dan X.

\section{Bentuk-bentuk Akronim Berdasarkan Jumlah Kata Pembentuknya}

1. Dua kata pembentuk: beti $\rightarrow$ be-ti $\rightarrow$ beda tipis

2. Tiga kata pembentuk: barito $\rightarrow \underline{\text { ba-ri-to }} \rightarrow \underline{\text { bawang } \underline{\text { rica }} \text { tomat }}$

3. Empat kata pembentuk: polos $\rightarrow$ po-los $\rightarrow$ poco-poco lonte sadis

4. Lima kata pembentuk: pupumatoli $\rightarrow$ pu-pu- $\underline{\text { ma }}-\underline{\text { to- }} \underline{\text { li }} \rightarrow$ pucuk pucuk mar $\underline{\text { torang }}$ linca

Terdapat 32 proses pembentukan akronim yang tidak mengikuti kaidah dari teori yang dikemukakan oleh Kridalaksana, di antaranya dapat dilihat pada daftar di bawah ini.

1) Akronim yang mengalami proses pembentukan berupa pengekalan huruf pertama (pada kata pertama) pada komponen pertama, dan pengekalan tiga huruf pertama (pada kata kedua) pada komponen kedua (i-mut: itang mutlak); 2) Akronim yang mengalami proses pembentukan berupa pengekalan huruf pertama (pada kata pertama) pada komponen pertama, dan pengekalan empat huruf pertama (pada kata

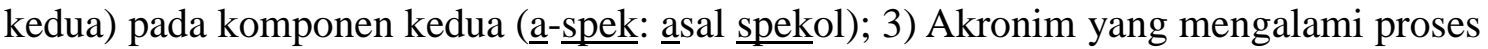
pembentukan berupa pengekalan tiga huruf pertama (pada kata pertama) pada komponen pertama, dan pengekalan dua huruf pertama (pada kata kedua) pada komponen kedua (nen-si: nenek sihir); 4) Akronim yang mengalami proses pembentukan berupa pengekalan dua huruf pertama (pada kata pertama) pada komponen pertama, pengekalan dua huruf pertama (pada kata kedua) dan huruf terakhir (pada kata kedua) pada komponen kedua (go-pek; gode pendek); 5) Akronim yang mengalami proses pembentukan berupa pengekalan tiga huruf pertama (pada kata pertama) pada komponen pertama, dan pengekalan empat huruf pertama (pada kata kedua) pada komponen kedua (sar-beng: saraf bengko); 6) Akronim yang mengalami proses pembentukan berupa pengekalan dua huruf pertama (pada kata pertama) pada komponen pertama, dan pengekalan lima huruf pertama (pada kata kedua) pada

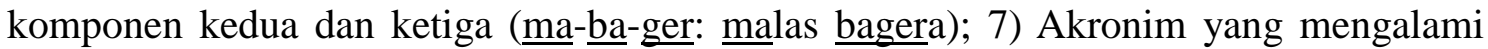
proses pembentukan berupa pengekalan empat huruf pertama (pada kata pertama) pada komponen pertama dan kedua, dan pengekalan dua huruf pertama (pada kata kedua) 
pada komponen ketiga (go-lo-pe: golojo pepe); 8) Akronim yang mengalami proses pembentukan berupa pengekalan dua huruf pertama (pada kata pertama) pada komponen pertama, pengekalan huruf ketiga, keempat dan keenam (pada kata pertama) pada komponen kedua, dan pengekalan tiga huruf terakhir (pada kata kedua) pada

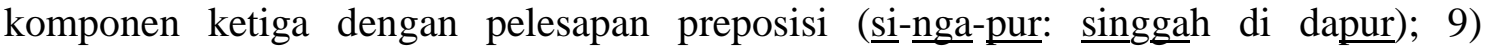
Akronim yang mengalami proses pembentukan berupa pengekalan dua huruf pertama (pada kata pertama) pada komponen pertama, pengekalan huruf keempat dan kelima (pada kata pertama) pada komponen pertama, dan pengekalan dua huruf pertama (pada

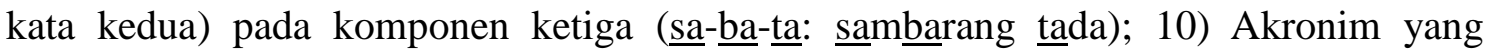
mengalami proses pembentukan berupa pengekalan dua huruf pertama dan satu huruf terakhir (pada kata pertama) pada komponen pertama, dan pengekalan dua huruf pertama (pada kata kedua) pada komponen kedua (ㅁk-so: $\underline{\text { batak }}$ soe); 11) Akronim yang mengalami proses pembentukan berupa pengekalan dua huruf pertama (pada kata pertama) pada komponen pertama, dan pengekalan dua huruf pertama dan huruf keempat (pada kata kedua) pada komponen kedua adalah sebagai berikut: (as-tuj: asal tunjung); 12) Akronim yang mengalami proses pembentukan berupa pengekalan dua huruf pertama (pada kata pertama) pada komponen pertama, dan pengekalan dua huruf pertama dan huruf kelima (pada kata kedua) pada komponen kedua ( $\underline{\mathrm{mu}}$-los: $\underline{\text { mulu }}$ longsor); 13) Akronim yang mengalami proses pembentukan berupa pengekalan huruf pertama (pada kata pertama) pada komponen pertama, pengekalan dua huruf pertama (pada kata kedua) pada komponen kedua, dan pengekalan huruf pertama (pada kata

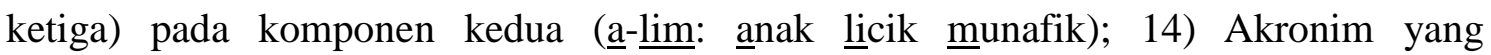
mengalami proses pembentukan berupa pengekalan dua huruf pertama (pada kata pertama) pada komponen pertama, pengekalan huruf pertama (pada kata kedua) pada komponen kedua dan pengekalan tiga huruf pertama (pada kata ketiga) pada komponen

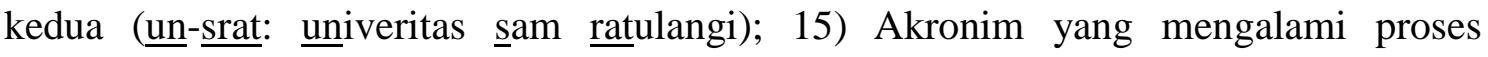
pembentukan berupa pengekalan dua huruf pertama (pada kata pertama) pada komponen pertama, pengekalan dua huruf pertama (pada kata kedua) pada komponen kedua, dan pengekalan huruf pertama (pada kata ketiga) pada komponen kedua (으-tab: doi tahun baru); 16) Akronim yang mengalami proses pembentukan berupa pengekalan dua huruf pertama (pada kata pertama) pada komponen pertama, pengekalan dua huruf pertama (pada kata kedua) pada komponen kedua, dan pengekalan huruf pertama (pada 
kata ketiga) pada komponen kedua dengan pelesapan reduplikasi (po-los: poco-poco lonte sadis); 17) Akronim yang mengalami proses pembentukan berupa pengekalan dua huruf pertama (pada kata pertama) pada komponen pertama, pengekalan dua huruf pertama (pada kata kedua) pada komponen kedua, dan pengekalan dua huruf terakhir

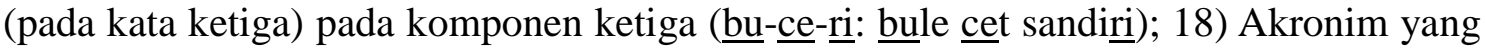
mengalami proses pembentukan berupa pengekalan dua huruf pertama (pada kata pertama) pada komponen pertama, pengekalan dua huruf pertama (pada kata kedua) pada komponen kedua, dan pengekalan dua huruf terakhir (pada kata ketiga) pada komponen kedua (uㅡ-pang: cucur panada apang); 19) Akronim yang mengalami proses pembentukan berupa pengekalan tiga huruf pertama (pada kata pertama) pada komponen pertama, pengekalan dua huruf pertama (pada kata kedua) pada komponen kedua, dan pengekalan huruf pertama (pada kata ketiga) pada komponen kedua (mantos: manado town square); 20) Akronim yang mengalami proses pembentukan berupa pengekalan tiga huruf pertama (pada kata pertama) pada komponen pertama, pengekalan dua huruf pertama (pada kata kedua) pada komponen kedua, dan pengekalan tiga huruf terakhir (pada kata ketiga) pada komponen ketiga (bra-ko-cah: brani kore picah).

\section{Faktor-faktor yang Menyebabkan Perbedaan Antara Penggunaan Akronim dalam} Bahasa Melayu Manado di Kalangan Guru dan Siswa di SMP Negeri 8 Manado

\section{Provinsi Sulawesi Utara}

Menurut Peter Trudgil, penggunaan bahasa dapat dipengaruhi oleh kelas sosial, kelompok etnis, jenis kelamin, situasi, interaksi sosial, kewarganegaraan, dan lingkungan tempat tinggal.

Faktor-faktor yang menyebabkan perbedaan penggunaan akronim dalam Bahasa Melayu Manado di kalangan guru dan siswa di SMP Negeri 8 Manado Provinsi Sulawesi Utara adalah:

1. Faktor Usia: guru-guru menggunakan jumlah akronim yang lebih sedikit dibandingkan para siswa.

2. Situasi dan interaksi: dalam berinteraksi dengan guru, siswa segan menggunakan akronim-akronim tertentu apalagi yang berkonotasi negatif. Mereka menghindari kesan dianggap tidak sopan oleh guru jika menggunakan akronim seperti polos 
(poco-poco lonte sadis), asigoma (anak hasil goyangan mama) dan sebagainya. Hal ini menyebabkan guru-guru di SMP Negeri 8 Manado tidak mengetahui dan tidak menggunakan akronim-akronim ini. Bentuk akronim seperti ini hanya diketahui oleh kalangan siswa saja.

\section{Kesimpulan}

Berdasarkan penelitian dan pembahasan masalah yang telah diuraikan pada babbab sebelumnya, maka dapat ditarik beberapa kesimpulan sebagai berikut:

1. Ditemukan 104 akronim di SMP Negeri 8 Manado dan 103 di antaranya sesuai dengan teori dari Kridalaksana (2009), McCully, Holmes (1988) dan Hartanto. Akronim yang digunakan di SMP Negeri 8 Manado berdasarkan klasifikasinya terdiri atas akronim yang terbentuk dari dua kata, tiga kata, empat kata dan lima kata. Berdasarkan proses pembentukannya ditemukan 30 proses pembentukan baru di luar teori Kridalaksana.

2. Faktor-faktor yang menyebabkan perbedaan penggunaan akronim dalam Bahasa Melayu Manado di kalangan guru dan siswa di SMP Negeri 8 Manado Provinsi Sulawesi Utara adalah faktor usia, situasi dan interaksi.

\section{DAFTAR PUSTAKA}

Al Fithriyah, N. 2013. "Variasi Bahasa pada Dialog Film Red Cobex: Kajian Sosiolinguistik." Skriptorium 1(2):81-93.

Ana, H. 2010. "Akronim dalam Bahasa Indonesia: Tinjauan Linguistik dan Sosio-Politis Perkembangannya." Linguistika 17(32).

Astuti, N. 2015. "Singkatan dan Akronim di Kalangan Remaja di Kota Bandung." Bandung: UPI.

Chomsky, N. 2002. Syntactic Structures. Berlin: de Gruyter.

Deliani, S. 2014. "Exploring Acronym in Indonesian Language; Structure Formation and Internal Syllable." IOSR Journal of Humanities and Social Science 19(3):20-24.

Dhianari, Ni Made. 2011. "Ragam Bahasa Kaskus.".

Giyatmi, Endang D. H., Wijayava, R. dan Arumi, S. 2014. "The Analysis of English Word Formations Used on Brand Names Found in Indonesian Products." Register 179-204.

Harimansyah, G. 2011. "Diksi Laki-laki dan Perempuan dalam Puisi - Mutakhir Indonesia (Kajian Sosiolinguistik-Genderistik)." Widyariset 14(1):143-152.

Hartanto, J. S. 1995. Pedoman Umum Pembentukan Istilah dan Pedoman EYD. Surabaya: Indah. 
Kasiram, H. M. 2010. Metodologi Penelitian Kualitatif dan Kuantitatif. Yogyakarta: UIN Maliki Press.

KBBI Daring. 2016. "Hasil Pencarian - KBBI Daring." (http://kbbi.kemendikbud.go.id/entri/bahasa).

Kerlinger, F. 1973. Foundation of Behavioral Research. Holt: Rinehart.

Kridalaksana, H. 1990. Kelas Kata dalam Bahasa Indonesia. Jakarta: PT Gramedia. Kurniasari, R. dan Budiman, M. 2014. "Pemilihan Bahasa pada Multibahasawan: Kajian Sosiolinguistik Pemilihan Bahasa pada Mahasiswa Kebumen di UI." Depok: Universitas Indonesia.

Mahsun. 2005. Metode Penelitian Bahasa Indonesia. Jakarta: Rajawali Press.

Marsono. 2011. Morfologi - Bahasa Indonesia dan Nusantara. Jogjakarta: Gadjah Mada University Press.

Marthawati, A. I. 2011. "Penggunaan Istilah, Deiksis, Singkatan, dan Akronim dalam Situs Jejaring Sosial Facebook."

McCully, C. B. dan Holmes, M. 1988. "Some Notes on the Structure of Acronyms." Lingua (74):27-43.

Merriam-Webster. 2016. "Definition of Acronym.” (https://www.merriamwebster.com/dictionary/acronym).

O’Grady, W. dan Dobrovolsky, M. 1987. Contemporary Linguistic Analysis - An Introduction. Toronto: Copp Clark Pitman Ltd.

Pateda, M. 1987. Sosiolinguistik. Bandung: Angkasa.

Plag, I. 2002. Word-formation in English. Cambridge: Cambridge University Press.

Prastya, T. 2014. "Analisis Bahasa Graffiti Tembok di Kota Surakarta: Tinjauan Sosiolinguistik." Surakarta: Universitas Muhammadiyah.

Samarin, W. J. 1988. Ilmu Bahasa Lapangan. Yogyakarta: Kanisius.

Susdamita, R. A., Faizah, H. dan Jalil, A. 2015. "Akronim dalam Indonesia Lawak Klub (ILK)." Jurnal Bahasa 217-224.

Trudgill, P. 1986. Sociolinguistics - An Introduction to Language and Society. Middlesex: Penguin Books, Ltd.

Warokka, D. 2004. Kamus Bahasa Daerah Manado-Minahasa. Jakarta: Alfa Indah Jakarta.

Zaim, M. 2015. "Pergeseran Sistem Pembentukan Kata Bahasa Indonesia: Kajian Akronim, Blending, dan Kliping." Linguistik Indonesia 173-192. 